\title{
Surgical Treatment of Recurrent Colorectal Cancer: Short and Long Term Outcomes
}

\section{Nüks Kolorektal Kanserde Cerrahi Tedavi: Kısa ve Uzun Dönem Sonuçlar}

\author{
(1) Nuri Okkabaz'1, (1) Mustafa Öncel2 \\ 1 İstanbul Bağcılar Training and Research Hospital, Clinic of General Surgery, İstanbul, Turkey \\ 2istanbul Medipol University Faculty of Medicine, Department of General Surgery, İstanbul, Turkey
}

\section{HIIIII| ABSTRACT}

Aim: The aim of this study was to investigate the effect of surgical margin positivity on short- and long-term outcomes in patients undergoing recurrent colorectal cancer surgery.

Method: Demographics, parameters related to primary tumor and previous surgery, recurrent tumor characteristics and perioperative features and long-term outcomes were compared between groups (R0 vs. Rl) according to surgical margin positivity.

Results: Of 57 patients who underwent surgery for recurrent colorectal cancer, 49 patients (86\%) in whom curative resection was achieved were included in the study. Eleven (22.4\%) cases had surgical margin positivity (R1) on pathological examination. Demographics, primary tumor localization, tumor stage, time to recurrence, adjuvant oncological treatments were comparable between R0 and R1 groups. Although the surgical procedures performed differed according to the location of the recurrent lesion, they were proportionally similar between the groups. The operative time, the amount of intraoperative bleeding, the need for transfusion, and the length of hospital stay were similar ( $>0.05$ for each variable). There were 17 (44.7\%) and four (36.4\%) postoperative complications in the R0 and Rl groups, respectively, but no difference was observed between the groups. Regional recurrence rate was $18.9 \%(n=7)$ in R0 group and $27.3 \%(n=3)$ in $R 1$ group, respectively ( $\mathrm{p}=0.675)$. Overall survival rates of R0 and Rl patients at 1,3 and 5 years were $78.4 \%$ vs. $81.8 \%$, ( $p=0.754$ ), $43.2 \%$ vs. $36.4 \%$, ( $p=0.720$ ) and $27.0 \%$ vs. $27.3 \%$ ( $p=0.866$ ), respectively.

Conclusion: Complications are higher after recurrent colorectal cancer surgery. This study emphasizes that microscopic surgical margin positivity (R1) may not adversely affect short- and long-term outcomes in patients operated for recurrent colorectal cancer, and that local recurrence rates of these cases may be similar to those with complete resection (R0).

Keywords: Recurrence, colorectal cancer, R0 resection, survival, complication

\section{|l||l|||| ÖZ}

Amaç: Nüks kolorektal kanser cerrahisi uygulanan hastalarda cerrahi sınır pozitifliğinin erken ve geç dönem sonuçlarını üzerine etkisini incelemektir. Yöntem: Nüks kolorektal kanser tanısıyla ameliyat edilen hastalarda cerrahi sınır pozitifliği durumuna göre demografik veriler, ilk hastalık ve operasyon bilgileri, nüks hastalık ve tedavi verileri ile uzun dönem sonuçları kıyaslandı.

Bulgular: Nüks kolorektal kanser nedeniyle ameliyat edilen 57 hastanın küratif amaçlı rezeksiyonun başarıldığı 49’u (\%86) çalışmaya dahil edildi. Bu olguların 11'inde $(\% 22,4)$ patoloji raporlarında cerrahi sınır pozitifliği (R1) saptandı. R0 ve Rl grupları demografik veriler, ilk tümörün yerleşim ve evresi ile nükse kadar geçen süre, uygulanan onkolojik tedaviler açılarından istatistiki farklılık göstermiyordu. Uygulanan cerrahi işlemler nüks lezyonun yerleşimine göre farklılık göstermekle beraber oransal olarak gruplar arasında benzerdi. Operasyon süresi, ameliyat sırasında kanama miktarı, transfüzyon ihtiyacı ve miktarı ile hastanede kalış süreleri benzerdi (her bir değişken için p>0,05). R0 ve R1 gruplarında \%44,7 ( $\mathrm{n=17}$ ) ve $\% 36,4(\mathrm{n}=4)$ oranlarında postoperatif komplikasyon izlendi, ancak gruplar arasında farklılık gözlenmedi. R0 ve Rl gruplarında yer alan hastalarda yeniden bölgesel tekrarlama oranları \%18,9 $(\mathrm{n}=7)$ ve $\% 27,3(\mathrm{n}=3)$ idi $(\mathrm{p}=0,675)$. Hastaların 1,3 ve 5 yıllık genel sağkalım oranları $(\% 78,4$ vs. \%81,8, $\mathrm{p}=0,754 ; \% 43,2$ vs. $\% 36,4, \mathrm{p}=0,720$ ve $\% 27,0$ vs. $\% 27,3, \mathrm{p}=0,866)$ idi.

Sonuç: Nüks kolorektal kanser ameliyatı sonrası komplikasyon oranları yüksektir. Bu çalışma nüks kolorektal kanser tanısı ile ameliyat edilen hastalarda mikroskobik cerrahi sınır pozitifliğinin (R1) erken ve geç dönem sonuçları olumsuz olarak etkilemeyebileceğini ve bu olguların lokal tekrarlama oranlarının tam rezeksiyon başarılan (R0) olgulara benzer olabileceğinin altını çizmektedir.

Anahtar Kelimeler: Nüks, kolorektal kanser, R0 rezeksiyon, sağkalım, komplikasyon

This study was partially presented as an oral presentation at the $17^{\text {th }}$ National Surgery Congress on 26-29 May 2010.

Address for Correspondence/Yazışma Adresi: Nuri Okkabaz MD,

İstanbul Bağcılar Training and Research Hospital, Clinic of General Surgery, İstanbul, Turkey

E-mail: n_okkabaz@yahoo.com ORCID ID: orcid.org/0000-0001-8962-2057

Received/Gelis Tarihi: 02.08.2019 Accepted/Kabul Tarihi: 04.08.2019

${ }^{\circ}$ Copyright 2019 by Turkish Society of Colon and Rectal Surgery

Turkish Journal of Colorectal Disease published by Galenos Publishing House. 


\section{Introduction}

Colorectal tumors are among the first three most common cancers that cause mortality in both women and men in our country. The treatment of the disease is multidisciplinary, but surgery constitutes an important stage of treatment. Regional recurrence can be seen after colorectal cancer surgery, whether applied for curative or palliative purposes. Although steps have been taken to develop and standardize neoadjuvant therapies and surgical techniques to reduce this risk, local recurrence rates after colon and rectal cancer surgeries have been reported to be 5-19\% and $3-33 \%$, respectively. ${ }^{1,2}$ The chance of re-reoperation is limited in such recurrences and is only possible in 13$30 \%$ of all cases. There are many studies on the surgical technique that can be performed in case of local recurrence and their outcomes. $3,4,5,6,7,8,9,10,11,12$ The surgery varies greatly due to many variables such as the location of the tumor, affected organs, presence or absence of metastases and accompanying diseases of the patient. This complicates both the measurement and demonstration of perioperative outcomes and does not allow comparison of different treatment modalities. However, it is believed that following oncological surgical principles provides a significant survival advantage. Two separate analyzes showed that median survival was prolonged from 5 months in patients without treatment to 7 and 15 months with radiotherapy. ${ }^{4,13}$ However, many studies have shown that the median survival time increases to 33 to 59 months and the 5-year survival rate increases to 30 to $54 \%$ if recurrent disease is completely excised. ${ }^{4,14}$ Surgical procedures performed to obtain this survival advantage are more radical interventions than primary tumor surgery due to unavailability of laparoscopic surgery, entering the previously operated abdomen, the need for multiple organ resections, and the need for neoadjuvant/adjuvant therapies. Therefore, intraoperative and early postoperative morbidity rates are higher. Some studies have reported perioperative complication rates between $15 \%$ and $68 \%$, and have reported that early mortality reaches $3 \%$. $3,6,7,14,15,16,17,18$ Especially in rectal cancer surgery, surgical margin positivity is an important problem and its relationship with local recurrence has been known for a long time. ${ }^{19}$ On the other hand, due to the nature of the disease and the difficulty of surgery, it is not possible to achieve surgical margin negativity in the case of recurrence as much as primary disease surgery. $3,5,6,10,12,20,21,22,23,24,25$ The effect of microscopic surgical margin on recurrence in these patients has not been elucidated. The aim of this study was to evaluate the short- and long-term outcomes of surgery in patients with recurrent colorectal cancer who were operated in our clinic and to compare the outcomes of patients with microscopically negative and positive surgical margins.

\section{Materials and Methods}

\section{Study Design and Inclusion Criteria}

All patients who are operated at Dr. Lütfi Kırdar Kartal Training and Research Hospital, Clinic of General Surgery are enrolled in a prospective database. The study was conducted by retrospectively reviewing this database for all patients who were operated for recurrent colorectal cancer between 2004 and 2012. Patients with less than 5 years from surgery to data analysis were excluded to examine longterm outcomes. The potential for surgery was evaluated by carcinoembryogenic antigen, colonoscopy, thoracic and abdominal computed tomography, abdominal and pelvis magnetic resonance imaging, and positron emission tomography computed tomography in recent years. Preoperative pathologic diagnosis was obtained in suspected patients or in patients in whom endoscopic biopsy could be done. The entire treatment process was managed by a multidisciplinary council, and the applicability of surgery and the need for neoadjuvant/adjuvant treatments were decided by this council. Palliative surgeries in cases with metastasis other than resectable liver metastases were excluded from the study. The main criterion for surgical indications was the removal of the entire disease with potential negative surgical margins. All surgical procedures were performed or supervised by a single colorectal surgeon (M.O.).

\section{Definitions}

Recurrent colorectal cancer was defined as tumor recurrence at the surgical resection site or due to dissemination of the disease during surgery without causing carcinomatosis. Following complete removal of the tumor, surgical margin $>1 \mathrm{~mm}$ was defines as R0, $1 \mathrm{~mm}$ or closer was defined as $\mathrm{R} 1$, and remaining macroscopic tumor after surgery or perioperative evaluation of the tumor as unresectable was defined as R2.

\section{The Analyzed Variables and Groups}

The following data were compiled: demographic data, data from the first surgery (tumor location, tumor, lymph node, metastases stage, surgical margins, operation performed, shape and center, preoperative and/or postoperative chemo/ radiotherapy status), surgical procedures for recurrence (type and duration of surgery, intraoperative hemorrhage, perioperative blood transfusion rate and amount of transfusion, postoperative complications, mortality and length of hospital stay) and long-term outcomes (follow-up time, local recurrence and distant metastasis rates, overall survival). Patients were divided into two groups as R0 and R1. The R2 group was also evaluated, identified, but comparison was made between groups $\mathrm{R} 0$ and $\mathrm{R} 1$. 


\section{Statistical Analysis}

SPSS 20.0 for Windows (IBM Corp. Released in 2011. Armonk, NY: IBM Corp) was used to analyze the data. Categorical data were expressed as number and percentage, and numerical data as mean \pm standard deviation or median (range). The distribution between the groups was evaluated by Kolmogorov-Smirnov test. The numerical data with normal distribution were compared using Student's t-test and non-normally distributed data were compared using Mann-Whitney U test. Categorical data were compared using chi-square test (Pearson or Fisher's exact test). The overall survival rates of the groups were compared using Kaplan-Meier method.

\section{Results}

Fifty-seven patients [mean age $=54.7 \pm 11.9$ years, 35 male (61.4\%)] who met the specified criteria and were operated for recurrent colorectal cancer were included in the study. Complete surgical resection failed in eight $(14.0 \%)$ of these patients and these patients were considered as $\mathrm{R} 2$ resection group. No resection was performed in five patients (8.8\%) in this group, and macroscopic residual tumor remained due to partial palliative resection in three patients (5.3\%) who underwent tumor resection, subtotal colectomy and small bowel resection. This group of patients was excluded from further analysis and the remaining 49 patients [mean age $=56.5 \pm 11.2$ years, 30 male $(61.2 \%)]$ were accepted as the subject of the study. Demographic data and data of the primary tumor were similar in these cases. Forty-one patients $(83.7 \%)$ were operated for primary tumors in other centers. Twenty seven patients (71.1\%) in the R0 group and 11 patients (100\%) in the $\mathrm{Rl}$ group received chemotherapy and/or radiotherapy before or after their first surgery $(\mathrm{p}=0.050)$ (Table 1$)$. The median time to recurrence in groups R0 and R1 was 28.5 (range=2-143) and 2 (range $=6-70)$ months, respectively $(\mathrm{p}=0.581)$. Neoadjuvant chemo/radiotherapy was applied after recurrence in four patients [three patients (7.9\%) in R0 and one patient $(9.1 \%)$ in $\mathrm{R} 1$ groups, $\mathrm{p}=0.767$ ]. Colon resections were higher in the R0 group ( $\mathrm{n}=16,42.1 \%)$ and rectal resections were higher in the $\mathrm{Rl}$ group $(\mathrm{n}=6,54.5 \%)$, but this difference did not lead to a significant difference $(\mathrm{p}=0.337)$ (Table 2$)$. The rate of need for additional organ resection was $61.2 \%$ (30/49) throughout the study and was similar between the groups. The most commonly resected organs were similar in the R0 and R1 groups. In the R0 group, four patients (10.5\%) underwent synchronous metastasectomy ( $\mathrm{p}=0.562)$. Intraoperative bleeding, operative time, intraoperative and postoperative blood transfusion requirements and hospital stay were similar in both groups (Table 2). Postoperative complications were observed in 21 cases $(42.9 \%)$ and complication rates were similar between the groups $(\mathrm{p}=0.737$ ) (Table 3). Early mortality was observed postoperatively in three patients $(5.3 \%)$ who underwent R0 resection. The causes of mortality were as follows: hemorrhagic shock due to intraoperative blood loss on the day of surgery, treatment-refractory uncompensated pulmonary edema on postoperative day 2 and treatment-refractory sepsis due to anastomotic leakage on postoperative day 23 . The median follow-up period was 35 (range=7-146) months in group

Table 1. Demographic and primary tumor data

\begin{tabular}{|c|c|c|c|}
\hline & $\begin{array}{l}\text { Group R0 } \\
(\mathrm{n}=38)\end{array}$ & $\begin{array}{l}\text { Group R1 } \\
(\mathrm{n}=11)\end{array}$ & $\mathrm{p}$ \\
\hline Age & $56.9 \pm 11.8$ & $54.9 \pm 9.2$ & 0.610 \\
\hline Gender (female/male) & $16(42.1) / 22(57.9)$ & $3(27.3) / 8(72.7)$ & 0.492 \\
\hline \multicolumn{4}{|l|}{ Primary tumor location } \\
\hline Right colon & $2(5.3)$ & 0 & \multirow{4}{*}{0.532} \\
\hline Transverse colon & $2(5.3)$ & 0 & \\
\hline Left colon & $16(42.1)$ & $3(27.3)$ & \\
\hline Rectum & $18(47.4)$ & $8(72.7)$ & \\
\hline \multicolumn{4}{|l|}{ Primary TNM stage* } \\
\hline 1 & $7(20.6)$ & $1(10.0)$ & \multirow{4}{*}{0.783} \\
\hline 2 & $15(44.1)$ & $6(60.0)$ & \\
\hline 3 & $11(32.4)$ & $3(30.0)$ & \\
\hline 4 & $1(2.9)$ & 0 & \\
\hline Neoadjuvant/adjuvant $\mathrm{CT} \pm \mathrm{RT}$ & $27(71.1)$ & $11(100)$ & 0.050 \\
\hline
\end{tabular}

*Histopathological data of primary tumor of four patients with R0 resection and one patient with Rl resection could not be reached, TNM: Tumor lymph node, metastases, CT: Chemotherapy, RT: Radiotherapy 
Table 2. Variables of recurrence surgery

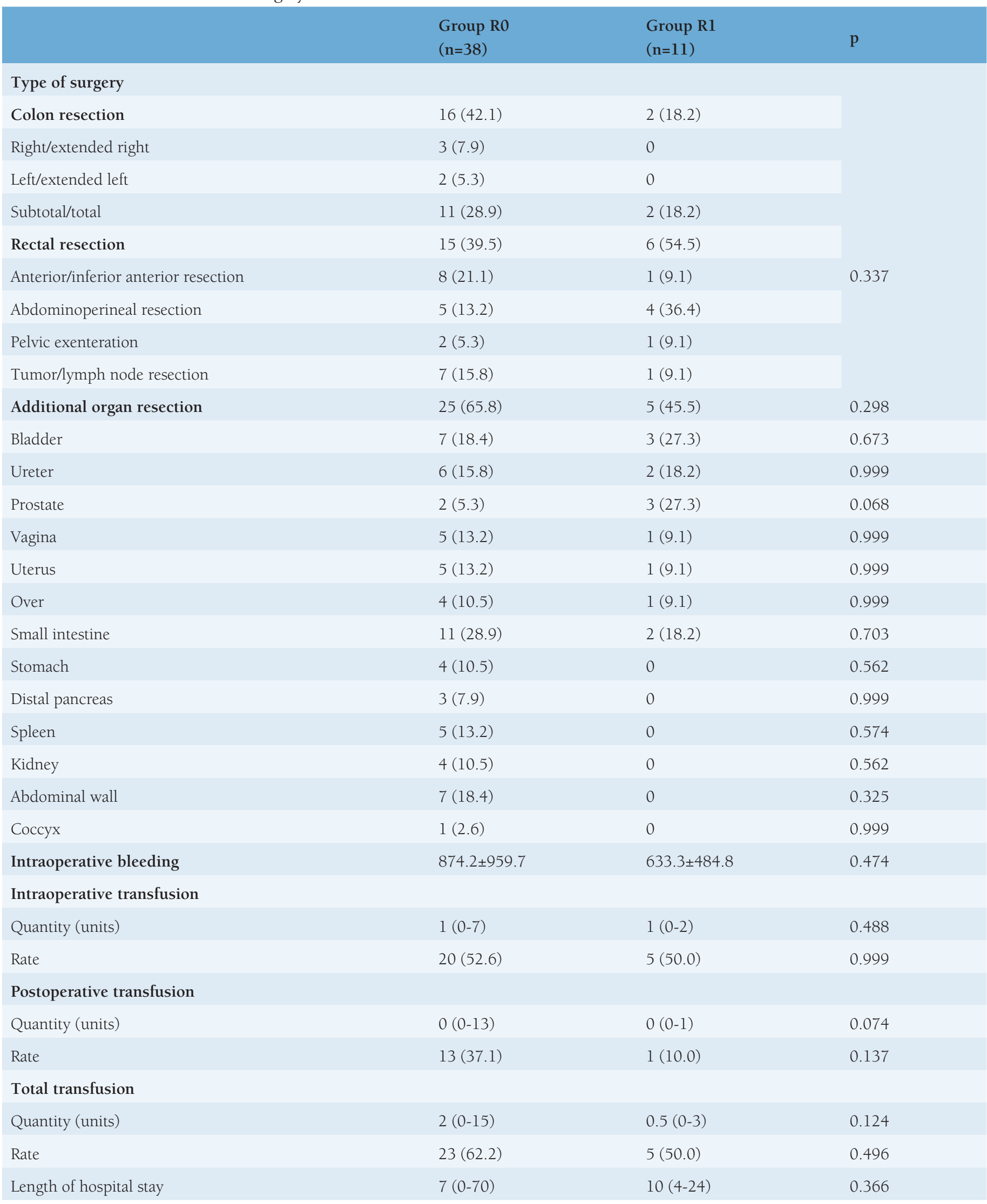


Table 3. Postoperative complications

\begin{tabular}{|c|c|c|c|}
\hline & $\begin{array}{l}\text { Group R0 } \\
(\mathrm{n}, \%)\end{array}$ & $\begin{array}{l}\text { Group R1 } \\
(\mathrm{n}, \%)\end{array}$ & $\mathrm{p}$ \\
\hline \multicolumn{3}{|c|}{ Clavien-Dindo Classification } & \multirow{5}{*}{0.928} \\
\hline Grade 1 & $6(15.8)$ & $2(18.2)$ & \\
\hline Grade 2 & $2(5.3)$ & $1(9.1)$ & \\
\hline Grade 3 & $7(18.4)$ & $1(9.1)$ & \\
\hline Grad 5 & $3(7.9)$ & 0 & \\
\hline Infective problems & $9(23.7)$ & 0 & 0.098 \\
\hline Wound site infection & $3(7.9)$ & 0 & 0.999 \\
\hline Evisceration & $4(10.5)$ & 0 & 0.562 \\
\hline Intraabdominal abscess & $3(7.9)$ & 0 & 0.999 \\
\hline Urinary fistula & $3(7.9)$ & $1(9.1)$ & 0.999 \\
\hline Ileus & $3(7.9)$ & $2(18.2)$ & 0.311 \\
\hline Nonsurgical problems & $2(5.3)$ & $1(9.1)$ & 0.542 \\
\hline Bleeding & $1(2.6)$ & 0 & 0.999 \\
\hline Enteric fistula & $1(2.6)$ & 0 & 0.999 \\
\hline Total & $17(44.7)$ & $4(36.4)$ & 0.737 \\
\hline
\end{tabular}

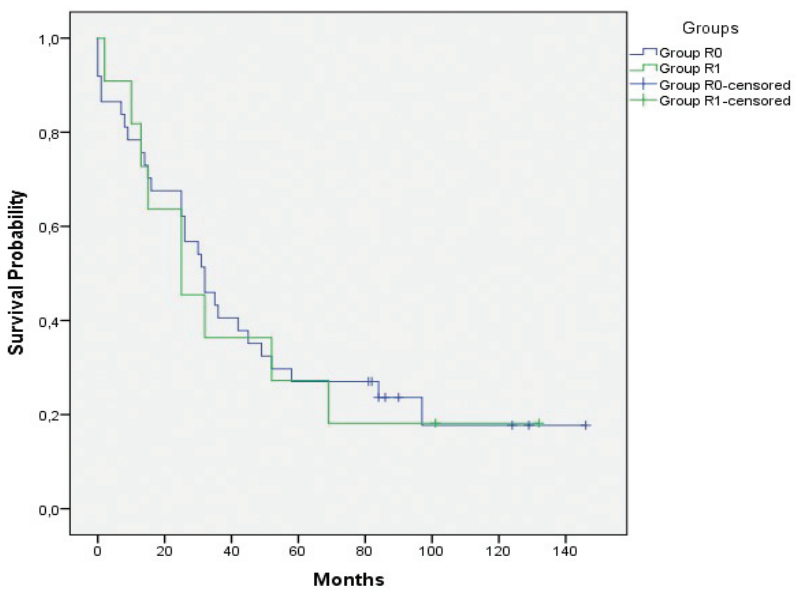

Figure 1. Kaplan-Meier analysis: overall survival rates

R0 and 25 months (range=2-132) in group R1 ( $\mathrm{p}=0.922$ ). During this period, the local recurrence rates in the R0 and R1 groups were $18.9 \%(n=7)$ and $27.3 \%(n=3)$, respectively ( $\mathrm{p}=0.675$ ). Overall survival rates of the patients at 1,3 and 5 years $(78.4 \%$ vs. $81.8 \%, \mathrm{p}=0.754,43.2 \%$ vs. $36.4 \%, \mathrm{p}=0.720$ and $27.0 \%$ vs. $27 \%, 3, \mathrm{p}=0.866$ ) were similar (Figure 1 ).

\section{Discussion}

In recurrent colorectal cancers, surgery has difficulties and success rates are lower than in primary cancers. It is known that surgery in accordance with oncologic rules provides a survival advantage in these patients, but the factors affecting the success of these complex operations have been studied less. ${ }^{3,6,8,11,16,22,24}$ It is not known whether surgical margin negativity, which has been shown to be effective in primary tumors, is necessary in recurrent cancer patients due to tumor character and surgical difficulty. The aim of this study was to define the surgical characteristics of recurrent colorectal cancer patients and to determine the effect of microscopic surgical margin positivity on short- and longterm outcomes.

There are many data suggesting that the recurrence rate of colorectal cancer is higher in male gender. ${ }^{4,5,7,10,16,20}$ In this series, more patients were male. However, no difference was found between R0 and R1 groups. In spite of all previous examinations and evaluations in recurrent colorectal cancer patients, it is not uncommon to detect the disease as unresectable during surgery. In a recent systematic review of nine studies including patients $(\mathrm{n}=950)$ operated for recurrent colon cancer, it was found that $\mathrm{R} 2$ resection rates in the series ranged from $7.1 \%$ to $62.9 \%$ (median $=22.6 \%$ ). ${ }^{26}$ The results are similar for rectal cancer. In another review specifically addressing this issue, $\mathrm{R} 2$ resection rates were reported to be between $2 \%$ and $48 \%$ (median $=14 \%$ ). ${ }^{9}$ In our series, the probability of failure of R0 or R1 resection was $14 \%$. In five out of eight patients, it was decided not to perform any resection during surgery and the possibility of 
a possible complication was minimized. We think that the main reason for this group of patients to be at an acceptable rate is related to the routine discussion of patients in multidisciplinary councils before surgery. Surgery for recurrent colorectal cancer includes larger areas of resection. In a previous study from our clinic, multiple organ resections were required in $25 \%$ of patients with primary colorectal cancer due to suspicion of T4 tumor, but the pathological T4 rate was found to be $8.8 \% .{ }^{27}$ However, due to its nature, recurrent cancers are significantly more likely to require multivisceral resection. In a single center study examining local and regional recurrences, 100 out of 744 patients underwent surgery, and 42 (42\%) required multiple organ resections. ${ }^{3}$ In the presented series, this rate was $62.2 \%$. The most commonly affected organs were the urinary system and small intestine. In our unit, primary T4 tumors or recurrent tumors that tend to exhibit environmental invasion due to its nature are most preferred for en block resection. This method may be advantageous in terms of tumor spread. On the other hand, large resections may increase postoperative risks. In some series, complication rates have been reported as $50 \%$ and mortality rates as $10 \%{ }^{10,21,23,28,29}$ In our series, postoperative complications were observed in 21 cases $(42.9 \%)$ and the complication rates between the groups were similar. Overall mortality rate was $6.1 \%(n=3)$. According to our opinion, recurrence operations are procedures that should be performed in reference centers because of technical difficulties, multidisciplinary approach and high postoperative complication rates. Survival results are not excellent, even if tumor resection has been successfully performed in patients with recurrent colorectal cancer. Although 5-year survival rate is reported as $90 \%$ in some small series, a recurrence rate of $25 \%$ and a $50 \%$ survival rate are reported for 3 years, even in cases where R0 is achieved. ${ }^{26,30}$ In a review of the results of recurrent rectal cancer surgery, recurrence rates were reported to be between $4 \%$ and 54\%, and 5-year survival rates between 9 and 39\%, even after curative surgery. ${ }^{9}$ Similar recurrence and survival rates were determined in our series. It has long been known that it is a vital requirement to achieve surgical margin negativity, especially during resection of primary tumors located in the rectum. ${ }^{19}$ For recurrent tumors, whether R0 and $\mathrm{R} 1$ resection really makes a difference is controversial. In a recent study involving mostly recurrence of colon cancer, survival differences between R0 and R1 resections could not be demonstrated. ${ }^{21}$ Another review reported that survival rates after R0 resection were significantly better than $\mathrm{R} 1$ resection. ${ }^{26}$ In our series, it is observed that the application of $\mathrm{R} 1$ resection is not a disadvantage in terms of both local recurrence and survival. This is an important finding in our opinion because these data make a further step unnecessary if more aggressive surgery is required to achieve the R0 limit, especially in patients with microscopic positivity. If these findings are confirmed by other series, it may be effective in determining the strategy during surgery and in the decision of the surgeon. This study has many limitations. The most important limitation is the problem posed by retrospective compilation of the data, despite the prospective recording of the data. The small number of the study population reduces the reliability of many inferences and raises doubts for statistically insignificant comparisons. The long study time renders the effects of the accumulation of experience and practical changes in the study results uncertain. Despite all of this, the study can be considered as efficient in terms of shedding light on the results of a rare surgical procedure.

\section{Conclusion}

In conclusion, surgery is difficult and often requires multiple organ resections in patients with recurrent colorectal cancer. This significantly increases the possibility of postoperative complications. Recurrence and survival results are not excellent in patients. However, Rl resection may not adversely affect the short- and long-term outcomes. Decision-making of such patients should be performed in multidisciplinary settings and performed by experienced surgeons.

\section{Ethics}

Ethics Committee Approval: Retrospective study.

Informed Consent: Retrospective study.

Peer-reviewed: Externally peer-reviewed.

\section{Authorship Contributions}

Surgical and Medical Practices: M.Ö., N.O., Concept: N.O., Design: M.Ö., Data Collection or Processing: N.O., Analysis or Interpretation: N.O., Literature Search: N.O., MÖ., Writing: N.O., MÖ.

Conflict of Interest: No conflict of interest was declared by the authors.

Financial Disclosure: The authors declared that this study received no financial support.

\section{References}

1. Furnée EJB, Allaix ME, Morino M. Long-term Oncologic Outcome After Laparoscopic Converted or Primary Open Resection for Colorectal Cancer: A Systematic Review of the Literature. Surg Laparosc Endosc Percutan Tech 2017;27:328-334.

2. Manfredi S, Bouvier AM, Lepage C, Hatem C, Dancourt V, Faivre J. Incidence and patterns of recurrence after resection for cure of colonic cancer in a well-defined population. Br J Surg 2006;93:1115-1122. 
3. Bowne WB, Lee B, Wong WD, Ben-Porat L, Shia J, Cohen AM, et al Operative salvage for locoregional recurrent colon cancer after curative resection: an analysis of 100 cases. Dis Colon Rectum 2005;48:897-909.

4. Bakx R, Visser O, Josso J, Meijer S, Slors JF, van Lanschot JJ. Management of recurrent rectal cancer: a population based study in greater Amsterdam. World J Gastroenterol 2008;14:6018-6023.

5. Pacelli F, Tortorelli AP, Rosa F, Bossola M, Sanchez AM, Papa V, et al. Locally recurrent rectal cancer: prognostic factors and long-term outcomes of multimodal therapy. Ann Surg Oncol 2010;17:152-162.

6. Heriot AG, Byrne CM, Lee P, Dobbs B, Tilney H, Solomon MJ, et al Extended radical resection: the choice for locally recurrent rectal cancer. Dis Colon Rectum 2008;51:284-291.

7. Harji DP, Sagar PM, Boyle K, Griffiths B, McArthur DR, Evans M. Surgical resection of recurrent colonic cancer. Br J Surg 2013;100:950-958.

8. Fuzun M, Terzi C, Sokmen S, Unek T, Haciyanli M. Potentially curative resection for locoregional recurrence of colorectal cancer. Surg Today 2004;34:907-912.

9. Nielsen MB, Laurberg S, Holm T. Current management of locally recurrent rectal cancer. Colorectal Dis 2011;13:732-742.

10. Palmer G, Martling A, Cedermark B, Holm T. A population-based study on the management and outcome in patients with locally recurrent rectal cancer. Ann Surg Oncol 2007;14:447-454.

11. Nielsen MB, Rasmussen PC, Lindegaard JC, Laurberg S. A 10-year experience of total pelvic exenteration for primary advanced and locally recurrent rectal cancer based on a prospective database. Colorectal Dis 2012;14:1076-1083.

12. Rahbari NN, Ulrich AB, Bruckner T, Münter M, Nickles A, Contin P, et al. Surgery for locally recurrent rectal cancer in the era of total mesorectal excision: is there still a chance for cure? Ann Surg 2011;253:522-533.

13. Allum WH, Mack P, Priestman TJ, Fielding JW. Radiotherapy for pain relief in locally recurrent colorectal cancer. Ann R Coll Surg Engl 1987;69:220221.

14. Haddock MG, Miller RC, Nelson H, Pemberton JH, Dozois EJ, Alberts $\mathrm{SR}$, et al. Combined modality therapy including intraoperative electron irradiation for locally recurrent colorectal cancer. Int J Radiat Oncol Biol Phys 2011;79:143-150.

15. Hahnloser D, Nelson H, Gunderson LL, Hassan I, Haddock MG, O'Connell MJ, et al. Curative potential of multimodality therapy for locally recurrent rectal cancer. Ann Surg 2003;237:502-508.

16. Asoglu O, Karanlik H, Muslumanoglu M, Igci A, Emek E, Ozmen V, et al. Prognostic and predictive factors after surgical treatment for locally recurrent rectal cancer: a single institute experience. Eur J Surg Oncol 2007;33:1199-1206.

17. Vermaas M, Ferenschild FT, Nuyttens JJ, Marinelli AW, Wiggers T, van der Sijp JR, et al. Preoperative radiotherapy improves outcome in recurrent rectal cancer. Dis Colon Rectum 2005;48:918-928.
18. Bergamaschi R, Pessaux P, Burtin P, Arnaud JP.Abdominoperineal resection for locally recurrent rectal cancer. Tech Coloproctol 2001;5:97-102.

19. Nagtegaal ID, van de Velde CJ, van der Worp E, Kapiteijn E, Quirke P, van Krieken JH et al. Macroscopic evaluation of rectal cancer resection specimen: clinical significance of the pathologist in quality control. J Clin Oncol 2002;20:1729-1734.

20. Westberg K, Palmer G, Hjern F, Johansson H, Holm T, Martling A. Management and prognosis of locally recurrent rectal cancer - A national population-based study. Eur J Surg Oncol 2018;44:100-107.

21. Suzuki K, Gunderson LL, Devine RM, Weaver AL, Dozois RR, Ilstrup DM, et al. Intraoperative irradiation after palliative surgery for locally recurrent rectal cancer. Cancer 1995;75:939-952.

22. Harris CA, Solomon MJ, Heriot AG, Sagar PM, Tekkis PP, Dixon L, et al. The Outcomes and Patterns of Treatment Failure After Surgery for Locally Recurrent Rectal Cancer. Ann Surg 2016;264:323-329.

23. Gwin JL, Hoffman JP, Eisenberg BL. Surgical management of nonhepatic intra-abdominal recurrence of carcinoma of the colon. Dis Colon Rectum 1993;36:540-544

24. Moore HG, Shoup M, Riedel E, Minsky BD, Alektiar KM, Ercolani M, et al. Colorectal cancer pelvic recurrences: determinants of resectability. Dis Colon Rectum 2004;47:1599-1606.

25. Bedrosian I, Giacco G, Pederson L, Rodriguez-Bigas MA, Feig B, Hunt KK, et al. Outcome after curative resection for locally recurrent rectal cancer. Dis Colon Rectum 2006;49:175-182.

26. Chesney TR, Nadler A, Acuna SA, Swallow CJ. Outcomes of resection for locoregionally recurrent colon cancer: A systematic review. Surgery 2016;160:54-66.

27. Gezen C, Kement M, Altuntas YE, Okkabaz N, Seker M, Vural S, et al. Results after multivisceral resections of locally advanced colorectal cancers: an analysis on clinical and pathological t4 tumors. World J Surg Oncol 2012;10:39.

28. Dresen RC, Gosens MJ, Martijn H, Nieuwenhuijzen GA, Creemers GJ, Daniels-Gooszen AW, et al. Radical resection after IORT-containing multimodality treatment is the most important determinant for outcome in patients treated for locally recurrent rectal cancer. Ann Surg Oncol 2008;15:1937-1947.

29. Wiig JN, Larsen SG, Giercksky KE. Operative treatment of locally recurrent rectal cancer. Recent Results Cancer Res 2005;165:136-147.

30. Hallet J, Zih FS, Lemke M, Milot L, Smith AJ, Wong CS. Neo-adjuvant chemoradiotherapy and multivisceral resection to optimize R0 resection of locally recurrent adherent colon cancer. Eur J Surg Oncol 2014;40:706712 . 